\title{
How do questionnaire definitions of atopy status affect sample size calculations for asthma cohort studies in a population of Canadian children?
}

\author{
Sarah Kwon ${ }^{1 *}$, Elinor Simons ${ }^{2}$, Teresa To ${ }^{2}$, Sharon D Dell ${ }^{1,2,3}$ \\ From Canadian Society of Allergy and Clinical Immunology Annual Scientific Meeting 2011 \\ Quebec, Canada. 20-23 October 2011
}

\section{Background}

Skin prick tests (SPT) are the gold standard for determining atopy. In epidemiological studies of childhood allergy, questionnaire responses are often used to define atopy and predict sample size. Questionnaire-reported hayfever symptoms have shown $28-76 \%$ sensitivity and 21-94\% specificity compared to SPT. We evaluated how questionnaire definitions of atopy affect sensitivity, specificity and sample size calculations in a population of Canadian children.

\section{Methods}

We used questionnaire data from 5619 Toronto schoolchildren participating in the $2006 \mathrm{~T}$-CHEQ study to determine 3 possible questionnaire definitions of atopy, including having any 1 , any 2 or all 3 parent-reported physician diagnoses of hayfever, eczema or food allergy. In a nested case-control sample of 208 of these children, atopy was evaluated by SPT to14 common aeroallergens. Using SPT as the gold standard for atopy, we calculated sensitivity, specificity and sample size for a nested cohort study of particulate exposure and atopy outcome.

\section{Results}

Compared with SPT, sensitivity, specificity and Youden's index were $54.3 \%, 65.8 \%$ and $20.1 \%$ for 1 reported atopic condition and $24.4 \%, 98.7 \%$ and $23.1 \%$ for 2 reported atopic conditions, respectively (Table 1 ). Requiring at least 2 positive SPT for atopy did not change the sensitivity or specificity. Sample size calculations required 344 and 2948 participants for atopy defined by 1 or 2 atopic conditions, respectively.

\section{Conclusions}

Questionnaire definitions of atopy in Canadian children have moderate sensitivity and specificity. More specific definitions decrease sensitivity and increase sample size requirement. Depending on the purpose of the proposed study, either definition of atopy may lead to an adequately-powered study.

Table 1 Sensitivity, specificity, PPV and NPV of questionnaire-based definitions of atopy compared to the gold standard of SPT and sample size calculations for a nested cohort study

\begin{tabular}{ccccccc}
\hline Number of atopic conditions & Sensitivity & Specificity & Youden's index & PPV & NPV & Sample size for nested cohort study \\
\hline $\mathbf{1}$ & $54.3 \%$ & $65.8 \%$ & $20.1 \%$ & $72.6 \%$ & $46.3 \%$ & 344 \\
$\mathbf{2}$ & $24.4 \%$ & $98.7 \%$ & $23.1 \%$ & $96.9 \%$ & $44.8 \%$ \\
$\mathbf{3}$ & $4.7 \%$ & $100.0 \%$ & $4.7 \%$ & $100.0 \%$ & $39.3 \%$ & 2948 \\
\hline
\end{tabular}

${ }^{1}$ Hospital for Sick Children, Department of Pediatrics, Toronto, ON, Canada,

M5G 1 X8

Full list of author information is available at the end of the article

(c) 2011 Kwon et al; licensee BioMed Central Ltd. This is an open access article distributed under the terms of the Creative Commons 


\section{Author details}

${ }^{1}$ Hospital for Sick Children, Department of Pediatrics, Toronto, ON, Canada,

M5G 1X8. ${ }^{2}$ Hospital for Sick Children, Child Health Evaluative Sciences,

Toronto, ON, Canada, M5G 1X8. ${ }^{3}$ Hospital for Sick Children, Division of

Respiratory Medicine, Toronto, ON, Canada, M5G 1X8.

Published: 14 November 2011

doi:10.1186/1710-1492-7-S2-A12

Cite this article as: Kwon et al:: How do questionnaire definitions of atopy status affect sample size calculations for asthma cohort studies in a population of Canadian children? Allergy, Asthma \& Clinical Immunology 2011 7(Suppl 2):A12.

Submit your next manuscript to BioMed Central and take full advantage of:

- Convenient online submission

- Thorough peer review

- No space constraints or color figure charges

- Immediate publication on acceptance

- Inclusion in PubMed, CAS, Scopus and Google Scholar

- Research which is freely available for redistribution

Submit your manuscript at www.biomedcentral.com/submit 